\title{
The influence of body condition score on serum metabolite profiles in Boer does before and after parturition
}

\author{
Dražen Đuričići ${ }^{1}$ Romana Gelli², Romana Turk ${ }^{3}$, Ivan Folnožićc \\ Jelena Šuran ${ }^{5}$, Damjan Gračner ${ }^{6}$, Hrvoje Valpotić 7 , Ivan Butković4 \\ and Marko Samardžija ${ }^{4 *}$ \\ ${ }^{1}$ Veterinary Practice Đurđevac, Croatia \\ ${ }^{2}$ Bormiamed d.o.o., Zagreb, Croatia \\ ${ }^{3}$ Department of Pathophysiology, Faculty of Veterinary Medicine, University of Zagreb, Zagreb, Croatia \\ ${ }^{4}$ Clinic of Obstetrics and Reproduction, Faculty of Veterinary Medicine, University of Zagreb, \\ Zagreb, Croatia \\ ${ }^{5}$ Department of Pharmacology and Toxicology, Faculty of Veterinary Medicine, University of Zagreb, \\ Zagreb, Croatia \\ ${ }^{6}$ Clinic for Internal Diseases, Faculty of Veterinary Medicine, University of Zagreb, Zagreb, Croatia \\ ${ }^{7}$ Department of Nutrition and Animal Husbandry, Faculty of Veterinary Medicine, University of Zagreb, \\ Zagreb, Croatia
}

\section{ĐURIČIĆ, D., R. GELLI, R. TURK, I. FOLNOŽIĆ, J. ŠURAN, D. GRAČNER, H. VALPOTIĆ, I. BUTKOVIĆ, M. SAMARDŽIJA: The influence of body condition score on serum metabolite profiles in Boer does before and after parturition. Vet. arhiv 87, 543-556, 2017.}

\section{ABSTRACT}

In goats, during the puerperal period, a lack of energy is one of the most frequent causes of sudden metabolic changes and the consequent reproductive disorders. The aim of our study was to assess the influence of the body condition on the serum profile of metabolites such as: total proteins (TP), albumin (ALB), triglycerides (TG), cholesterol (CHOL), glucose (GLU) and $\beta$-hydroxybutirate (BHB) in Boer goats during late pregnancy (Day 120), at parturition (Day 0) as well as on Days 30 and 60 after parturition. A total of 15 female Boer goats (does), from a commercial farm in north western Croatia were used. The body condition status of the goats was established using the standard protocol for scoring. Based on the body condition score (BCS), each doe was categorized into one of three groups: group $1(n=5)$ or obese does with BCS $\geq 3.50-5.00$, group $2(n=5)$ or medium does with $\mathrm{BCS} \geq 2.75<3.50$ and group $3(\mathrm{n}=5)$ or thin does with $\mathrm{BCS}<2.75$. The concentrations of

\footnotetext{
${ }^{*}$ Corresponding author:

Prof. Marko Samardžija, PhD, MSc, DVM, Clinic of Obstetrics and Reproduction, Faculty of Veterinary Medicine, University of Zagreb, Heinzelova 55, 10000 Zagreb, Croatia, Phone: +385 12390 321; Fax: +385 12441 390; E-mail: smarko@vef.hr
} 
D. Đuričić et al.: Body condition score and serum metabolites in Boer does

serum TP, ALB, TG, CHOL, GLU and BHB were measured spectrophotometrically. On Day 120 of pregnancy the level of TG was significantly higher $(\mathrm{P}<0.05)$ in the obese does than the medium does. The levels of TP or CHOL were significantly higher $(\mathrm{P}<0.05)$ in the obese than in the thin does on Day 30 and Day 60 , respectively, following parturition. The recorded changes in the metabolites tested could be of significance for monitoring the metabolic status of goats during intensive production, and of practical interest for preventing/controlling economic losses in goat breeding.

Key words: body condition score, serum biochemical parameters, pregnancy, lactation, Boer goats

\section{Introduction}

In general, goats are seasonal, polyestric animals in parts of the World with a continental climate, which means that they have regular ovarian cyclic activity only in certain seasons of the year. However, in tropical areas goats have regular cyclic activity throughout the entire year (DELGADILLO et al., 2004). In these cases, temperature, precipitation and vegetation availability are more important than photoperiod (HAMBOLU and OJO, 1985). When a breed of goats from a moderate continental climate is introduced into tropical areas, after a certain period of time they have regular cyclic activity in the new climate (ZARROUK et al., 2001).

It has been assumed that Boer goats may kid three times in two years in areas with a moderate climate due to the fact that they originated from the southern hemisphere. Namely, they still have native characteristics from their primary habitat in southern Africa, such as regular cyclic activity with the peak of sexual activity in autumn and with the decreased sexual activity in late spring and midsummer (GREYLING, 1990). It has been recognized that almost 30 years after the introduction of Boer goats in Europe, and assuming that their climatic adaptation ended during that period, this breed is showing characteristics of seasonal polyestric activity (ĐURIČIĆ et al., 2008; ĐURIČIĆ et al., 2012). The duration of pregnancy in goats is biologically variable and genetically inherited, but it is on average 150 days. The period of pregnancy is influenced by genetics and breed, as well as paragenetic factors such as: nutrition, nursing, management, climate, season, number of foetuses etc. (SAMARDŽIJA et al., 2010). According to GREYLING (1990), pregnancy in Boer goats in South Africa was 148.2 \pm 3.7 days, whereas in Croatia it is almost the same (148.36 \pm 0.86 days) (ĐURIČIĆ et al., 2009). In contrast to the dairy goat breeds, for whom it is desirable for lactation to be prolonged as much as possible, in Boer goats, which are a meat breed, the kids are of main economic interest to the farmer. Thus, the main interest of intensive production of Boer does is shortening the inter-kidding period so that the animals conceive as soon as possible after kidding (ĐURIČIĆ et al., 2008).

For proper nutrition and management procedures, goat breeders have accepted body condition scoring (BCS; ranging in scale from 1 to 5) as an effective and simple method to help them maintain and improve productive/reproductive efficiency in their 


\section{D. Đuričić et al.: Body condition score and serum metabolites in Boer does}

flocks. Factors that may influence BCS, besides nutrition, are: genotype, breed, age, sex, physiological status and environmental conditions (SAMARDŽIJA et al., 2013). After kidding and during lactation, it is expected that BCS may be reduced. In ideal farming conditions, BCS should never decrease below 2, and should never increase close to 5 (SANTUCCI et al., 1991).

The relevant indicators of the physiological status of goats in intensive production are their serum biochemical parameters, which may change depending on the following factors: breed, sex, age, nutrition, physiological conditions (pregnancy and lactation), and the influence of disease, stress and seasonal climatic variations (KHALED et al., 1999; ZUMBO et al., 2007; BANI ISMAIL et al., 2008; TSCHUOR et al., 2008; TANRITANIR et al., 2009; TURK et al., 2012). Changed levels of specific serum biochemical parameters may indicate not only the appearance of disorders or pathological conditions, but also induce feedback signals to the hypothalamus-pituitary-ovaries axis regarding alterations in metabolic status. Thus, precise measurement of metabolic parameters are of importance for an explanation of the possible effects of a disturbed metabolism on the cyclic activities of the ovaries in ruminants during the puerperium (OPSOMER et al., 1999; TURK, 2011).

For the proper reproductive efficiency of small ruminants, a positive energetic balance, characterized by deposition of energy in fat tissue in the form of lipids, is of crucial importance (MORA et al., 2007). On the other hand, when the energy status of goats is negative, the animals mobilize their fat depots and consequently lose body weight and condition (MENDIZABAL et al., 2011). This negative energy status, as well as underfeeding, suppress the pulsatile release of GnRH from the hypothalamus (ZULU et al., 2002) which delays the return of ovarian cyclic activity (DE VRIES and VEERKAMP, 2000; TURK et al., 2011; TURK et al., 2013). Namely, as soon as the regular ovarian cyclic activity is re-established, with visible signs of oestrus, goats may become pregnant earlier.

The aim of our study was to assess the influence of body condition on the serum profile of metabolites, such as: total proteins (TP), albumin (ALB), triglycerides (TG), cholesterol (CHOL), glucose (GLU) and $\beta$-hydroxybutirate (BHB) in Boer goats during late pregnancy (Day 120), at parturition (Day 0) as well as on Days 30 and 60 after parturition.

\section{Materials and methods}

Animals and BCS categorization. A total of 15 Boer does were used, aged between 2 and 7 years from a commercial farm (N $46^{\circ} 04^{\prime} 30^{\prime \prime}$ and Longitude E $17^{\circ} 05^{\prime} 74^{\prime \prime}$ ) in north western Croatia. The does were housed in individual boxes at a single breeding facility, managed and fed a diet according to the rearing technology of the farm. Bucks and does were serologically negative to brucellosis (Brucella melitensis), and coprological examinations were also negative. All does were kept together with their kids until weaning 
at the age of 3 to 4 months. At the beginning of the study the body condition status of the experimental does was established using the standard protocol for scoring, in accordance with a scale from 1 to 5 . On the basis of the body condition score (BCS) obtained, each doe was categorized into one of three groups (5 goats in each group): group 1 or obese does with $\mathrm{BCS} \geq 3.50-5.00$, group 2 or medium does with $\mathrm{BCS} \geq 2.75<3.50$ and group 3 or thin does with $\mathrm{BCS}<2.75$.

Feeding. According to the standard farming practice, the does had free access to good quality meadow hay (approximately $2.2-2.5 \mathrm{~kg}$ daily per animal), drinking water $\mathrm{ad}$ libitum and were fed twice a day with a concentrate mixture of either $0.60 \mathrm{~kg}$ during late pregnancy or $0.90 \mathrm{~kg}$ during lactation/animal/day, respectively. The concentrate during the pregnancy comprised $42 \%$ corn, $16 \%$ soybean meal with $44 \%$ crude protein, $15 \%$ oats, $15 \%$ barley, $9 \%$ wheat flour and 3\% mineral and vitamin supplements for goats. The chemical composition of the concentrate during lactation was: $87.44 \%$ dry matter, $17.06 \%$ crude protein, $4.96 \%$ crude fibre, $7.38 \%$ ash, $3.10 \%$ crude fat, $1.32 \%$ calcium, $0.57 \%$ phosphorous as well as vitamins A $15000 \mathrm{IE}, \mathrm{D} 1980 \mathrm{IE}$ and E $30 \mathrm{mg}$ and minerals, such as Zn $180 \mathrm{mg}$, Fe $60 \mathrm{mg}$, Mn $120 \mathrm{mg}$, Co $0.60 \mathrm{mg}$, I $3.0 \mathrm{mg}$ and Se $0.65 \mathrm{mg}$.

Blood sampling and serum biochemistry. Blood sampling was performed by $v$. jugularis puncture using a vacutainer on Day 120 of pregnancy, at birth (Day 0) and on Days 30 and 60 following parturition. The samples were kept for approximately 1 hour at room temperature and centrifuged at $700 \mathrm{~g}$ for $15 \mathrm{~min}$. The sera were separated and stored at $-20{ }^{\circ} \mathrm{C}$ until analysed. In the obtained blood serum, the concentrations of glucose (GLU), total proteins (TP), total cholesterol (CHOL), triglycerides (TG) and $\beta$-hydroxybutyrate (BHB) were determined by the standard spectrophotometric methods, using commercial kits (Olympus Diagnostica GMBH, Hamburg, Germany) on an Olympus AU 600 analyser.

Statistical analyses. The obtained data were statistically analysed by ANOVA using the program Statistica 12 (StatSoft, Dell, USA). Normal distribution of analysed data was validated by the Kolmogorov-Smirnov and Shapiro-Wilk tests. After that, one way ANOVA was performed in order to determine the significance of differences between the experimental parameters obtained from the three groups of does within the period of late pregnancy (Day 120), immediately after birth (Day 0), and on Days 30 and 60 following parturition. Corrections were determined between the experimental parameters. Also, the relationships were determined between the data on biochemical parameters within the groups of does, as well as their correlative associations. Differences between the experimental parameters were considered statistically significant at $\mathrm{P}<0.05$. 


\section{D. Đuričić et al.: Body condition score and serum metabolites in Boer does}

\section{Results}

The values obtained for serum biochemical parameters, i.e. metabolites TP, ALB, TG, CHOL and GLU and BHB, in Boer does categorized by BCS into three groups (obese, medium or thin) were determined on Day 120 of pregnancy (Table 1), immediately after birth (Day 0; Table 2), as well as on Days 30 and 60 following parturition (Table 3 and Table 4, respectively).

On Day 120 of pregnancy the level of TG was significantly higher $(\mathrm{P}<0.05)$ in the does from Group 1 than that in Group 2 (Table 1). There were no differences in the levels of the tested biochemical parameters between BCS-categorized Boer does on Day 0 of the experiment, i. e. immediately post-partum (Table 2). The levels of either TP or CHOL were significantly higher $(\mathrm{P}<0.05)$ in the does from Group 1 than those in Group 3 on Day 30 and Day 60, respectively, following parturition (Table 3 and Table 4).

Changes in the levels of serum biochemical parameters in these Boer does, categorized by BCS into three groups during the experimental period from Day 120 of pregnancy to Day 60 following parturition, were observed for TG (Fig. 1), TP (Fig. 2) and CHOL (Fig. 3). The level of TG obtained in Group 1 on Day 120 following parturition was significantly higher, at $\mathrm{P}<0.05$, than that in Group 2 (Fig. 1). The level of TP obtained in Group 1 on Day 30 following parturition was significantly higher, at $\mathrm{P}<0.05$, than that in Group 3 (Fig. 2). The level of CHOL obtained in Group 1 on Day 60 following parturition was significantly higher, at $\mathrm{P}<0.05$, than that in Group 3 (Fig. 3).

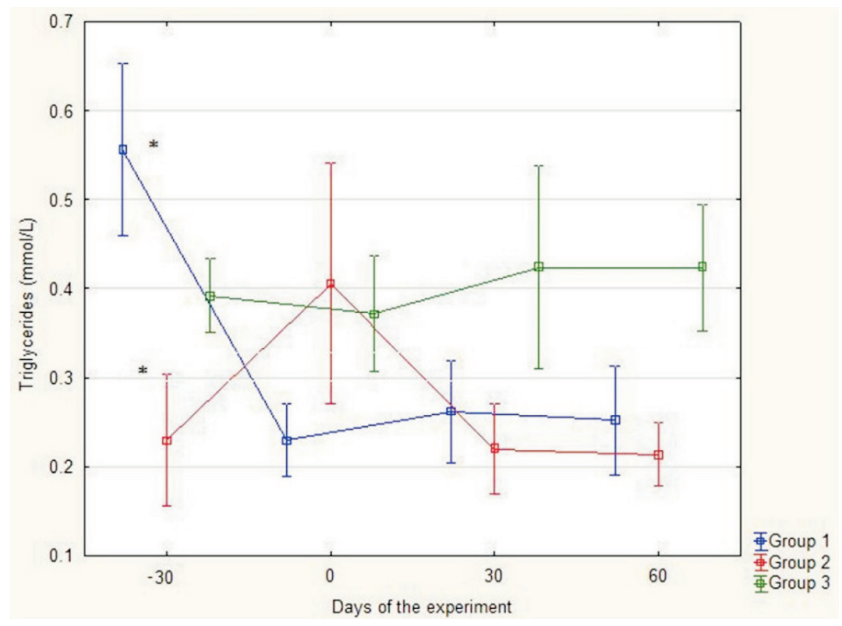

Fig. 1. Time course changes of serum triglyceride (TG) level (Mean \pm SD) in Boer does categorized by BCS into three groups (1,2 and 3) during the experimental period from Day 120 of pregnancy

(Day -30$)$ to Day 60 following parturition; * Values ( 1 vs. 2 ) differ significantly at $\mathrm{P}<0.05$. 
D. Đuričić et al.: Body condition score and serum metabolites in Boer does

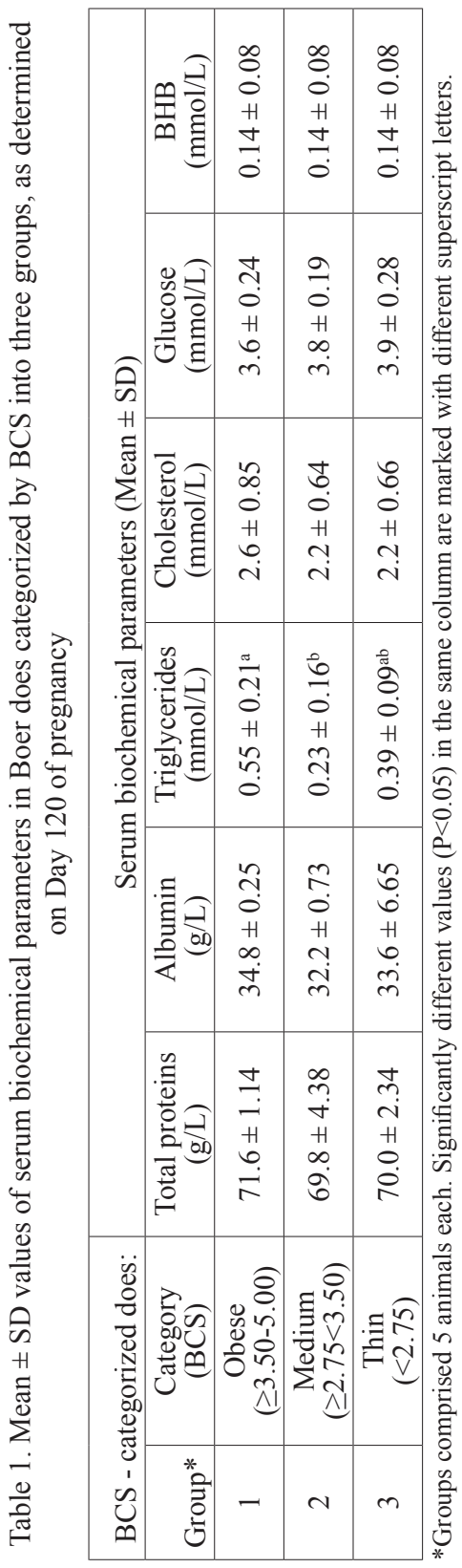

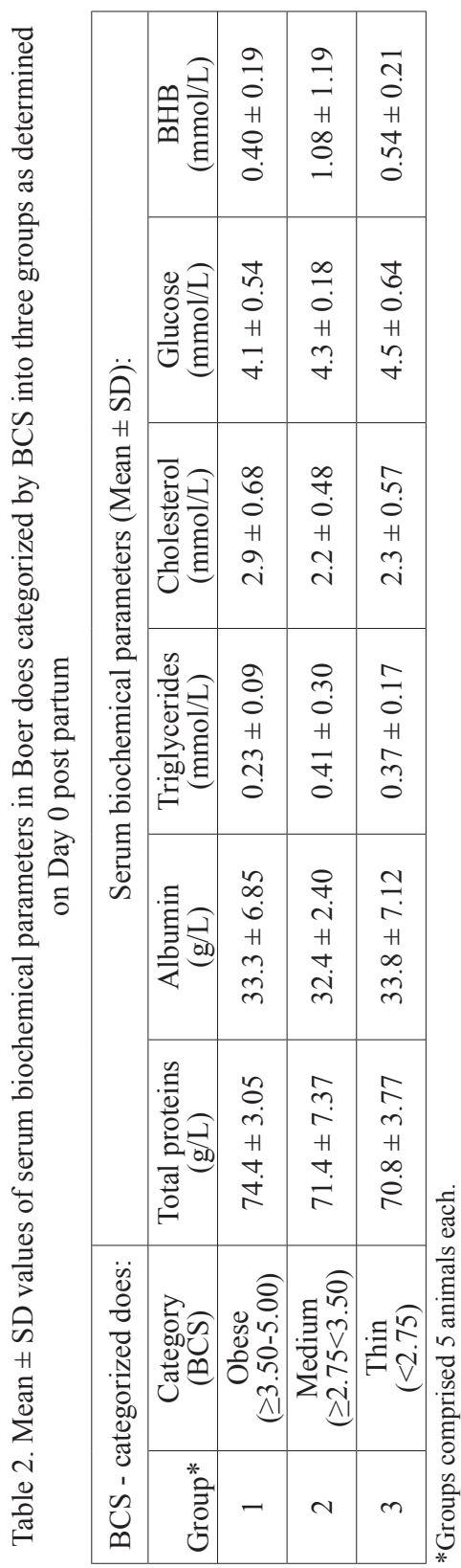

Vet. arhiv 87 (5), 543-556, 2017 
D. Đuričić et al.: Body condition score and serum metabolites in Boer does
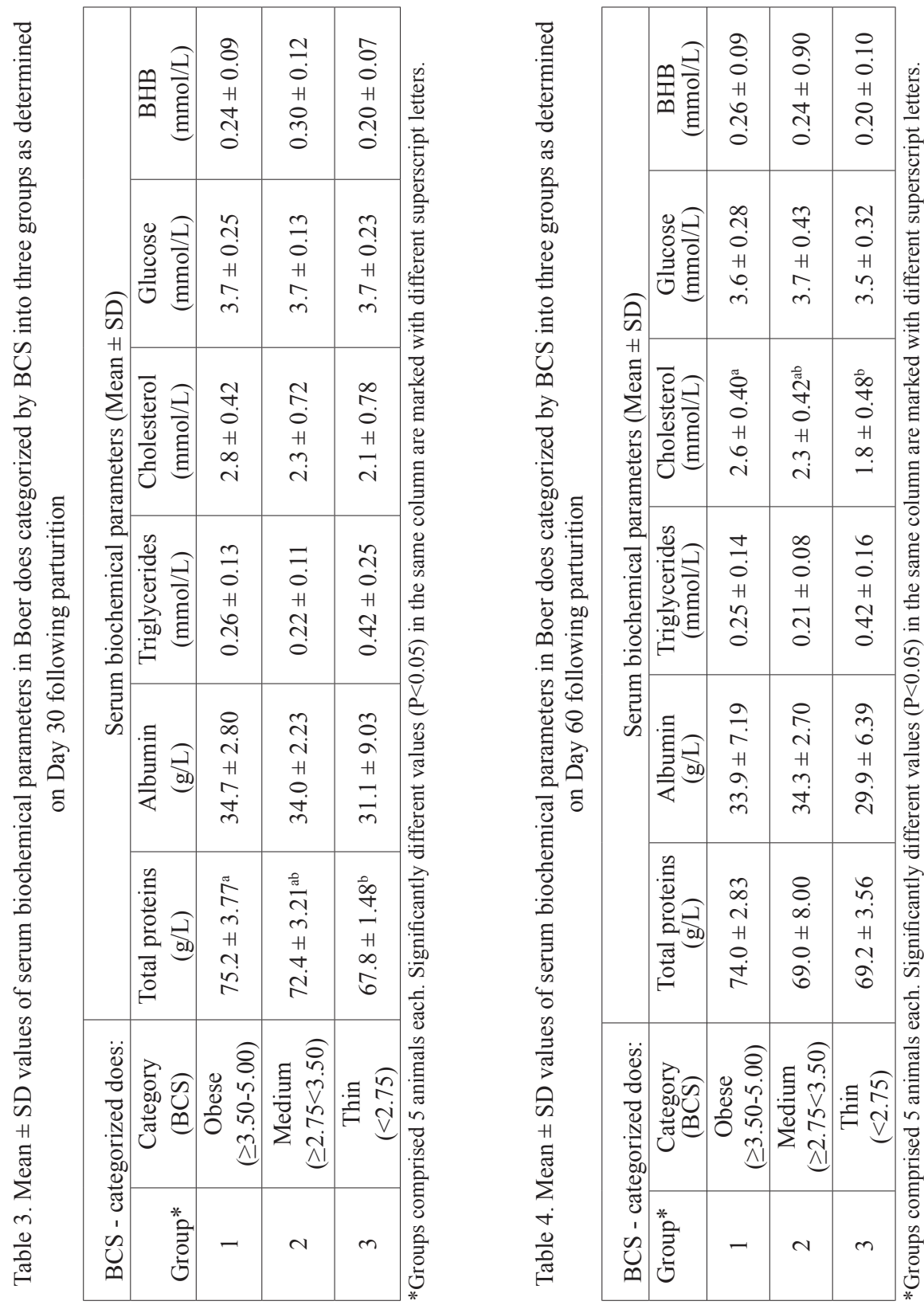

Vet. arhiv 87 (5), 543-556, 2017 
D. Đuričić et al.: Body condition score and serum metabolites in Boer does

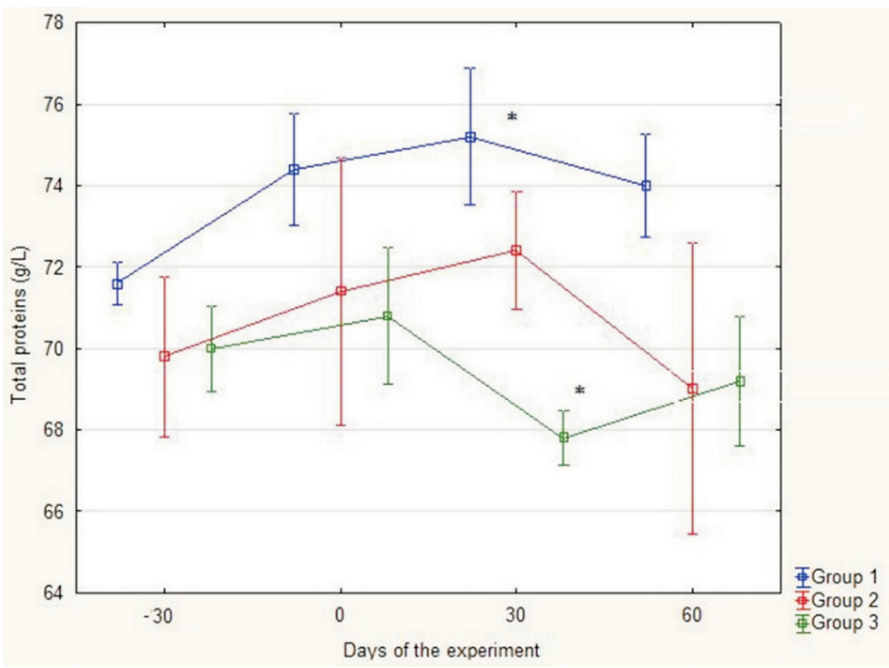

Fig. 2. Time course changes of serum total protein (TP) level (Mean \pm SD) in Boer does categorized by BCS into three groups (1, 2 and 3) during the experimental period from Day 120 of pregnancy

(Day -30) to Day 60 following parturition; * Values (1 vs. 3) differ significantly at $\mathrm{P}<0.05$.

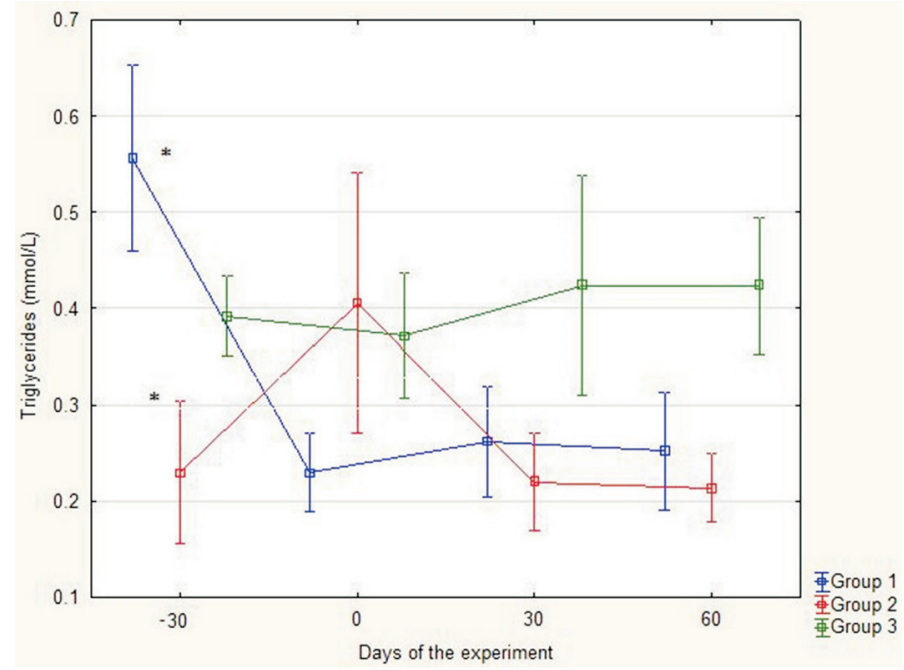

Fig. 3. Time course changes of serum cholesterol (CS) level (Mean \pm SD) in Boer does categorized by BCS into three groups (1, 2 and 3) during the experimental period from Day 120 of pregnancy

(Day -30) to Day 60 following parturition; *Values ( 1 vs. 2) differ significantly at $\mathrm{P}<0.05$. 


\section{D. Đuričić et al.: Body condition score and serum metabolites in Boer does}

\section{Discussion}

In intensive dairy goat production, the loss of body condition is a common problem, particularly at the peak of lactation. Unlike dairy goat breeds, Boer goats are very well adapted to survive in the nutrition deficient conditions of its indigenous habitat (ERASMUS, 2000; MALAN, 2000). However, in intensive production systems these goats are frequently over fed and tend to be obese due to their efficient deposition of body reserves (SAMARDŽIJA et al., 2013). The nutritional strategy in goat breeding has to be based on the production goal, the availability of feed and the specific nutritional requirements of particular breed (BARBOSA et al., 2009; LÉRIAS et al., 2015). Meat producing goats should be fed intensively during critical breeding phases, such as mating, pregnancy and early lactation (MIOČ and PAVIĆ, 2000). In order to increase the index of kidding, during the breeding season breeding goats should be in "reproductive" body condition, i. e. they should have a medium BCS, neither too thin nor obese (MENDIZABAL et al., 2011).

The average values of serum biochemical parameters were within the physiological ranges for Boer does during the experimental period. According to ĐURIČIĆ et al. (2011) does had the highest level of TP at the beginning of lactation. KRAJNICAKOVA et al. (2003) determined levels of TP ranging from $65.00 \pm 3.16$ to $71.79 \pm 2.83 \mathrm{~g} / \mathrm{L}$ during puerperium in dairy does, which were slightly lower levels than in the Boer does determined in our study. We established that the values of TP were the highest in the group of obese does, but they were only significantly different $(\mathrm{P}<0.05)$ from the group of thin does on Day 30 of lactation. In our study the levels of serum ALB and GLU did not differ significantly between the BCS-categorized does before and after parturition.

Despite the significant differences in TP level between does from group 1 and group 3 , we did not find any significant differences between all the three groups of BSCcategorized does in levels of ALB. It is likely that such an increase in serum TP level could be associated with an increase in the quantity of globulin fraction within TP, which could be induced by inflammatory response and/or by stress in group 3 does on Day 30 following parturition.

The levels of TG were not significantly different in the serum of pregnant and nonpregnant Saanen goats in Turkey (SERIN et al., 2010). The Boer goats had a significantly higher level of TG than dairy goats during puerperium (ĐURIČIĆ et al., 2008). NAZIFI et al. (2002) determined serum concentrations of TG in clinically healthy goats ranging from $0.11 \pm 0.03 \mathrm{mmol} / \mathrm{L}$ to $0.22 \pm 0.04 \mathrm{mmol} / \mathrm{L}$, which is much lower than in our study. CASAMASSIMA et al. (2007) reported that the values of TG were the same during late gravidity and early lactation in Montefalcone goats in Italy, which is different from our findings in Boer goats, that had higher levels in late pregnancy than in early lactation. Also, the level of TG was significantly higher on Day 120 of pregnancy in the obese does in comparison to the medium does. This could be explained by the fact that obese does 
have physiologically higher levels of serum TG due to excessive intake of fats, and/or metabolic disorders caused by alterations in liver and/or pancreas function.

KANEKO et al. (2008) established a physiological range of total CHOL in the blood serum of goats from $2.07 \mathrm{mmol} / \mathrm{L}$ to $3.36 \mathrm{mmol} / \mathrm{L}$. Slightly lower values of CHOL ( 2.06 $\pm 0.43 \mathrm{mmol} / \mathrm{L}$ to $2.75 \pm 0.01 \mathrm{mmol} / \mathrm{L}$ ) were recorded in dairy goats during puerperium KRAJNICAKOVA et al. (2003). BARBOSA et al. (2009) found similar values for total CHOL in the first eight weeks after parturition: $2.83 \mathrm{mmol} / \mathrm{L}$ for the thin goats, $2.16 \mathrm{mmol} / \mathrm{L}$ for the medium goats and $2.19 \mathrm{mmol} / \mathrm{L}$ for the obese goats. In our study, the levels of $\mathrm{CHOL}$ were higher in obese does during late pregnancy, after parturition and during lactation, which is in contrast to data reported by BARBOSA et al. (2009).

The body condition did not influence the energy status of the Boer does during the peripartum period, which could be seen from the levels of GLU and BHB, that were not significantly changed either before and after parturition, or between the BCS-categorized groups of does. However, the levels of BHB, which were rather low on Day 120 of pregnancy in all three groups of does, increased immediately after parturition, but not significantly, and then substantially returned to lower values on Day 30 and Day 60 following parturition.

The values of BHB in the blood serum of dairy goats (French-alpine breed) were twice as high in thin goats than in medium and obese goats after parturition (BARBOSA et al., 2009). However, we found BHB values twice as high in the Boer does categorized as medium in comparison to the thin and obese does $(1.08 \mathrm{mmol} / \mathrm{L} v s .0 .40 \mathrm{mmol} / \mathrm{L}$ and $0.54 \mathrm{mmol} / \mathrm{L}$ ), respectively, but these differences were not significant. According to our previous findings of BHB levels in Boer goats kept and fed under the same conditions (ĐURIČIĆ et al., 2011), we assumed that BHB values would not differ from our previous results during pregnancy and puerperium. We confirmed this in the current study.

After parturition, during the period of lactation, the needs for energy and macroand microelements in goats are increased in relation to the quantity and quality of milk, which in turn reduces body weight and body condition (SAMARDŽIJA et al., 2011). The level of GLU in the blood serum of goats suddenly decreases after parturition, and then substantially increases until the end of lactation (HUSSAIN et al., 1996). The latter finding is in agreement with our data on GLU levels before and after parturition. According to KANEKO et al. (2008) blood GLU values in goats range from $2.74 \mathrm{mmol} / \mathrm{L}$ to $4.18 \mathrm{mmol} / \mathrm{L}$. Lower values of GLU in blood serum were reported by ANTUNOVIĆ et al. (2006) for dairy goats raised in organic production, goats kept on pasture, and goats fed low energy feed (McDOUGALL et al., 1991; KHALED et al., 1999; ŽUBČIĆ, 2001). The concentration of GLU was found to be higher in dairy goats which were not in lactation, in comparison to lactating dairy goats (PAMBU-GOLLAH et al., 2000) as well as to meat breeds of goats (ĐURIČIĆ et al., 2008). Immediately after parturition BARBOSA et al. (2009) recorded 
higher levels of GLU than physiological levels, in the blood serum of goats. However, the level of GLU was lower in the medium than in the thin and obese does. In our study, the Boer does categorized as medium and thin had higher levels of GLU after parturition, and these were higher than physiological values, in contrast to the obese does, which had the GLU levels within the physiological range.

Altogether, it may be concluded that body condition had an impact on serum levels of TP, TG and CHOL, which could be seen to reflect either a decrease in feed intake in the does categorized as thin, or an increase in feed intake in the does categorized as obese.

The analyses of serum biochemical parameters tested in does from late pregnancy, at parturition and during the period of lactation may contribute to a better understanding of the metabolic changes in Boer does before and after parturition regarding their body condition. Also, such analyses may be of significance for monitoring the metabolic status of goats during intensive production, and could be of practical interest for improvement of goat breeding, as well as for preventing/controlling economic loses in food animal production.

\section{References}

ANTUNOVIĆ, Z., M. ŠPERANDA, D. SENČIĆ, V. ŠERIĆ, T. ŠPERANDA, D. GUTZMIRTL (2006): Blood metabolic profile of dairy goats in organic production. Krmiva 48, 231-236.

BANI ISMAIL, Z. A., A. M. AL-MAJALI, F. AMIREH, O. F. AL-RAWASHDEH (2008): Metabolic profile in goat does in late pregnancy with and without subclinical pregnancy toxemia. Vet. Clin. Pathol. 37, 434-437.

BARBOSA, L. P., M. T. RODRIGUES, J. D. GUIMARÃES, V. V. MAFFILI, L. S. AMORIM, A. F. GARCEZ NETO (2009): Body condition and metabolic profile of Alpine goats at the onset of lactation. Rev. Bras. de Zootec. 38, 2007-2014.

CASAMASSIMA, D., M. PALAZZO, R. PIZZO (2007): Evaluation of milk production and some blood parameters in lactating autochthonous goat extensively reared in Molise region. Ital. J. Anim. Sci. 6, 615-617.

DE VRIES, M. J., R. F. VEERKAMP (2000): Energy balance of dairy cattle in relation to milk production variables and fertility. J. Dairy Sci. 83, 62-69.

DELGADILlO, J. A., G. FITZ-RODRIGUEZ, G. DUARTE, F. G. VELIZ, E. CARILLO, J. A. FLORES, J. VIELMA, H. HERNANDEZ, B. MALPAUX (2004): Management of photoperiod to control caprine reproduction in the subtropics. Reprod. Fertil. Develop. 6, 471-478.

ĐURIČIĆ, D., J. GRIZELJ, T. DOBRANIĆ, I. HARAPIN, S. VINCE, P. KOČILA, I. FOLNOŽIĆ, M. LIPAR, G. GREGURIĆ-GRAČNER, M. SAMARDŽIJA (2012): Reproductive performance of Boer goats in a moderate climate zone. Vet. arhiv 82, 351-358.

ĐURIČIĆ, D., T. DOBRANIĆ, M. SAMARDŽIJA, S. VINCE, J. GRIZELJ (2009): Fruchtbarkeitsmerkmale der Burenziegen im nordwestlichen Teil Kroatiens. Tierärztl. Umschau 64, 384-388. 
D. Đuričić et al.: Body condition score and serum metabolites in Boer does

ĐURIČIĆ, D., T. DOBRANIĆ, J. GRIZELJ, D. GRAČNER, I. HARAPIN, D. STANIN, I. FOLNOŽIĆ, I. GETZ, D. CVITKOVIĆ, M. SAMARDŽIJA (2011): Concentrations of total proteins and albumins, and AST, AP, CK and GGT activities in the blood sera Boer and Saanen goats during puerperium. Reprod. Domest. Anim. 46, 674-677.

ĐURIČIĆ, D., T. DOBRANIĆ, M. SAMARDŽIJA, I. HARAPIN, S. VINCE, J. GRIZELJ, N. PRVANOVIĆ, D. GRAČNER, Lj. BEDRICA, D. CVITKOVIĆ (2008): Analyse der Ovarienaktivität der Burenziegen im Puerperium mit Hilfe des Stoffwechsel- und Hormonprofils. Tierärztl. Umschau 63, 370-376.

ERASMUS, J. A. (2000): Adaptation to various environments and resistance to disease of the improved Boer goat. Small Rumin. Res. 36, 179-187.

GREYLING, J. P. C. (1990): Sexual activity of the Boer goat. Boer Goat News 9, 51-53.

HAMBOLU, J. O., S. A. OJO (1985): Ovarian activity of Sokoto red goats using abbatoir specimens. Theriogenology 23, 273-282.

HUSSAIN, Q., O. HAVREVOLL, L. O. EIK, E. ROPSTAD (1996): Effects of energy intake on plasma glucose, non-esterified fatty acids and aceto-acetate concentration in pregnant goats. Small Rumin. Res. 21, 89-96.

KANEKO, J. J., W. HARVEY, M. L. BRUSS (2008): Clinical Biochemistry of Domestic Animals, $6^{\text {th }}$ edition Academic Press, San Diego, London, Boston, New York, Sydney, Tokyo, Toronto.

KHALED, N. F., J. ILLEK, S. GAJDUSEK (1999): Interactions between nutrition, blood metabolic profile and milk composition in dairy goats. Acta Vet. Brno 68, 253-258.

KRAJNICAKOVA, M., G. KOVAC, M. KOSTECKY, I. VALOCKY, I. MARACEK, I. SUTIAKOVA, L. LENHARDT (2003): Selected clinico-biochemical parameters in puerperal period of goats. Bull. Vet. Inst. Pulawy 47, 177-182.

LÉRIAS, J. R., R. PEÑA, L. E. HERNÁNDEZ-CASTELlANO, J. CAPOTE, N. CASTRO, A. ARGÜEllo, S. S. ARAÚJO, Y. SACO, A. BASSOlS, A. M. AlMEIDA (2015): Establishment of the biochemical and endocrine blood profiles in the Majorera and Palmera dairy goat breeds: the effect of feed restriction. J. Dairy Res. 82, 416-425.

MALAN, S. W. (2000): The improved Boer goat. Small Rumin. Res. 36, 165-170.

McDOUGALL, S., E. E. LEPHERD, S. SMITH (1991): Haematological and biochemical reference values for grazing Saanen goats. Austr. Vet. J. 68, 370-372.

MENDIZABAL, J. A., R. DELFA, A. ARANA, A. PURROY (2011): Body condition score and fat mobilization as management tools for goats on native pastures. Small Rumin. Res. 98, 121-127.

MIOČ, B., V. PAVIĆ (2002): Kozarstvo. Hrvatska mljekarska udruga, Zagreb.

MORA, O., H. VERA-AVILA, A. SHIMADA (2007): Cellular and endocrine mechanisms affected by under nutrition in small ruminants. Ciencia Vet. 10, 107-135.

NAZIFI, S., H. R. GHEISARI, F. SHAKER (2002): Serum lipids and lipoproteins and their correlations with thyroid hormones in clinically healthy goats. Vet. arhiv 72, 249-257. 
D. Đuričić et al.: Body condition score and serum metabolites in Boer does

OPSOMER, G., Y. T. GROHN, J. HERTL, H. LAEVENS, M. CORYN, A. DEKRUIF (1999): Protein metabolism and the resumption of ovarian cyclicity postpartum in high yielding dairy cows. Reprod. Domest. Anim. (Suppl. 6), Proceedings of the $3^{\text {rd }}$ Conference of the European Society for Domestic Animal Reproduction.

PAMBU-GOLLAH, R., P. B. CRONJÉ, N. H. CASEY (2000): An evaluation of the use of blood metabolite concentrations as indicators of nutritional status in free-ranging indigenous goats. South Afr. J. Anim. Sci. 30, 115-120.

SAMARDŽIJA, M., D. ĐURIČIĆ, T. DOBRANIĆ, M. HERAK, S. VINCE (2010): Reproduction in sheep and goats. Faculty of Veterinary Medicine University of Zagreb, Croatia. (in Croatian).

SAMARDŽIJA, M., S. VINCE, D. ĐURIČIĆ (2013): Association of parity, fecundity and body condition score with blood serum concentration of some metabolites during pre and post parturient period in German Improved Fawn goats. Vet. arhiv 83, 469-477.

SAMARDŽIJA, M., T. DOBRANIĆ, M. LIPAR, I. HARAPIN, N. PRVANOVIĆ, J. GRIZELJ, G. GREGURIĆ-GRAČNER, V. DOBRANIĆ, B. RADIŠIĆ, D. ĐURIČIĆ (2011): Comparison of blood serum macrominerals concentrations in meat and dairy goats during puerperium. Vet. arhiv 81, 1-11.

SANTUCCI, P. M., A. BRANCA, M. NAPOLEONE R. BOUCHE, G. AUMONT, F. POISOT, G. ALEXANDRE (1991): Body condition scoring of goats in extensive conditions. In: Goat Nutrition, (Morand-Fehr, Ed.), Pudoc, Wageningen.

SERIN, I., G. SERIN, M. YILMAZ, F. KIRAL, A. CEYLAN (2010): The effects of body weight, body condition score, age, lactation, serum trygliceride, cholesterol and paraoxonase levels on pregnancy rate of Saanen goats in breeding season. J. Anim. Vet. Adv. 9, 1848-1851.

TANRITANIR, P., S. DEDE, E. CEYLAN (2009): Changes in some macro minerals and biochemical parameters in female healthy Siirt hair goats before and after parturition. J. Anim. Vet. Adv. 8, 530-533.

TSCHUOR, A. C., B. RIOND, U. BRAUN, H. LUTZ (2008): Hämatologische und klinisch chemische Referenzwerte für Ziegen und Schafe. Schweiz. Arch. Tierheilk. 150, 287-295.

TURK, R. (2011): Metabolic Profiling to Assess Health Status. In: Production Diseases of Dairy Animals. (Sharma, N., N. Kumar Singh, G. Bačić, Eds.). Delhi: Satish Serial Publishing House.

TURK, R., C. PIRAS, M. KOVAČIĆ, M. SAMARDŽIJA, H. AHMED, M. DE CANIO, A. URBANI, Z. FLEGAR MEŠTRIĆ, A. SOGGIU, L. BONIZZI, P. RONCADA (2012): Proteomics of inflammatory and oxidative stress response in cows with subclinical and clinical mastitis. J. Proteomics 75, 4412-4428.

TURK, R., M. SAMARDŽIJA, G. BAČIĆ (2011): Oxidative stress and reproductive disorders in dairy cows. In: Dairy Cows: Nutrition, Fertility and Milk Production. (Marek, E. Russell, Ed.). New York, USA: Nova Science Publishers, Inc.

TURK, R., O. PODPEČAN, J. MRKUN, M. KOSEC, Z. FLEGAR-MEŠTRIĆ, S. PERKOV, J. STARIČ, M. ROBIĆ, M. BELIĆ, P. ZRIMŠEK (2013): Lipid mobilisation and oxidative stress as metabolic adaptation processes in dairy heifers during transition period. Anim. Reprod. Sci. $141,109-115$. 
D. Đuričić et al.: Body condition score and serum metabolites in Boer does

ZARrouK, A, O. SOUILEM, P. V. RION, J. F. BECKERS (2001): Caracteristiques de la reproduction de l'espece caprine. Ann. Med. Vet. 145, 98-105.

ZULU, V. C., Y. SAWAMUKAI, K. NAKADA, K. KIDA, M. MORIYOSHI (2002): Relationship among insulin-like growth factor-I, blood metabolites and postpartum ovarian function in dairy cows. J. Vet. Med. Sci. 54, 879-885.

ZUMBO, A., R. DI ROSA, S. CASELLA, G. PICCIONE (2007): Changes in some blood haematological parameters of Maltese goats during lactation. J. Anim. Vet. Adv. 6, 706-711.

ŽUBČIĆ, D. (2001): Some biochemical parameters in blood of grazing German improved Fawn goats from Istria, Croatia. Vet. arhiv 71, 237-244.

Received: 12 May 2016

Accepted: 15 July 2016

\begin{abstract}
ĐURIČIĆ, D., R. GELLI, R. TURK, I. FOLNQŽIĆ, J. ŠURAN, D. GRAČNER, H. VALPOTIĆ, I. BUTKOVIĆ, M. SAMARDŽIJA: Utjecaj tjelesne kondicije na metaboličke serumske pokazatelje u burske koze prije i nakon jarenja. Vet. arhiv 87, 543-556, 2017.

\section{SAŽETAK}

U koze tijekom puerperija nedostatak energije predstavlja jedan od najčešćih uzroka iznenadnih metaboličkih promjena i posljedičnih reprodukcijskih poremećaja. Cilj našeg istraživanja bio je procijeniti utjecaj tjelesne kondicije na serumske metabolite kao što su: ukupni proteini (UP), albumin (ALB), trigliceridi (TG), kolesterol (CHOL), glukoza (GLU) i $\beta$-hidroksimaslačna kiselina (BHB) u burskih koza tijekom kasne gravidnosti (120. dan), porođaja (0. dan) kao i na 30. i 60. dan nakon porođaja. Ukupno je korišteno 15 burskih koza iz komercijalne farme u sjeverozapadnoj Hrvatskoj. Status tjelesne kondicije (engl. body condition score, BCS) koza utvrđen je uporabom standardnog protokola za ocjenu. Na temelju ocjene BCS svaka je koza kategorizirana u jednu od 3 skupine od po 5 životinja u svakoj: 1 . skupina - pretile (BCS $\geq 3,50-5,00), 2$. skupina - srednjeg gojnog stanja $(B C S \geq 2,75-3,50)$ i 3 . skupina - mršave $(B C S \leq 2,75)$. Koncentracije serumskih UP, ALB, TG, CHOL, GLU i BHB bile su određivane spektrofotometrijski. Na 120. dan gravidnosti razina TG bila je značajno viša $(\mathrm{P}<0,05)$ u pretilih koza nego u koza srednjeg gojnog stanja. Razine UP i CHOL bile su značajno više $(\mathrm{P}<0,05)$ u pretilih nego u mršavih koza 30., odnosno 60. dana nakon porođaja. Zabilježene promjene u istraživanih metabolita mogle bi biti od značenja za praćenje metaboličkog statusa koza tijekom intenzivne proizvodnje, a mogle bi biti i od praktične vrijednosti za prevenciju i kontrolu gospodarskih gubitaka u uzgoju koza.
\end{abstract}

Ključne riječi: tjelesna kondicija, serum, biokemijski pokazatelji, gravidnost, laktacija, burske koze 